\title{
AEROMAGNETIC MAP OF PARTS OF THE RALPH AND NORWAY QUADRANGLES DICKINSON COUNTY, MICHIGAN
}

\author{
GEOPHYSICAL INVESTIGATIONS \\ MAP GP- 610
}

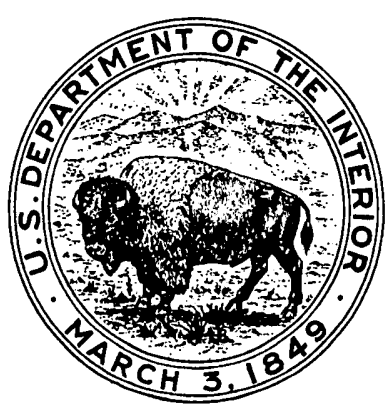

